University of New Hampshire

University of New Hampshire Scholars' Repository

$12-2008$

\title{
The nature and dynamics of internet pornography exposure for youth.
}

Chiara Sabina

Pennsylvania State University - Main Campus

Janis Wolak

University of New Hampshire - Main Campus

David Finkelhor

University of New Hampshire - Main Campus, David.Finkelhor@unh.edu

Follow this and additional works at: https://scholars.unh.edu/soc_facpub

Part of the Sociology Commons

\section{Recommended Citation}

Sabina, C., Wolak, J., Finkelhor, D. The nature and dynamics of internet pornography exposure for youth. (2008) Cyberpsychology and Behavior, 11 (6), pp. 691-693.

This Article is brought to you for free and open access by the Sociology at University of New Hampshire Scholars' Repository. It has been accepted for inclusion in Sociology Scholarship by an authorized administrator of University of New Hampshire Scholars' Repository. For more information, please contact Scholarly.Communication@unh.edu. 


\title{
Rapid Communication
}

\section{The Nature and Dynamics of Internet Pornography Exposure for Youth}

\author{
Chiara Sabina, Ph.D., ${ }^{1}$ Janis Wolak, J.D., ${ }^{2}$ and David Finkelhor, Ph.D. ${ }^{2}$
}

\begin{abstract}
We examined exposure to Internet pornography before the age of 18 , as reported by college students $(n=563)$, via an online survey. Ninety-three percent of boys and $62 \%$ of girls were exposed to online pornography during adolescence. Exposure prior to age 13 was relatively uncommon. Boys were more likely to be exposed at an earlier age, to see more images, to see more extreme images (e.g., rape, child pornography), and to view pornography more often, while girls reported more involuntary exposure. If participants in this study are typical of young people, exposure to pornography on the Internet can be described as a normative experience, and more study of its impact is clearly warranted.
\end{abstract}

\section{Introduction}

S UBSTANTIAL NUMBERS OF youth Internet users are exposed to online pornography. ${ }^{1,2}$ Despite extensive worry about the potential impact, there is still little research on this topic. The current study used an online survey to question a convenience sample of college students about experiences with online pornography before age 18 . Due to known differences between boys and girls with regard to pornography, we compared genders.

\section{Method}

We asked professors at a New England public university to recruit undergraduates to participate in an online survey regarding exposure to online pornography. As an incentive, participants could enter a raffle for one of ten $\$ 100$ checks. We gathered 594 responses; $12 \%$ of 4,992 students in the classes of 48 professors who voluntarily participated. The final sample totaled 563 , of which $34 \%(n=192)$ was male, the median age was $19,93.4 \%$ identified as white, and $72 \%$ as freshmen or sophomores.

We asked participants about (a) demographics; (b) age of first exposure to online pornography, if any; (c) consumption of 10 particular types of images; (d) reasons for viewing; and (e) whether they had seen online pornography be- fore age 18 that had a strong effect on their attitudes or emotions. Responses were anonymous, and raffle entry occurred on another Web site. Data collection took place during Spring semester 2006.

\section{Results}

Overall, $72.8 \%$ of participants $(93.2 \%$ of boys, $62.1 \%$ of girls, $p<0.001$ ) had seen online pornography before age 18 . (See Table 1.) Most exposure began when youth were ages 14 to 17, and boys were significantly more likely to view online pornography more often and to view more types of images. Considerable numbers of boys and girls had seen images of paraphilic or criminal sexual activity, including child pornography and sexual violence, at least once before the age of 18. Girls were significantly more likely than boys $(42.3 \%$ of girls; $6.8 \%$ of boys, $p<0.001)$ to report never looking for pornography on purpose, indicating they were involuntarily exposed.

A small minority of participants, $12.0 \%$ of boys $(n=20)$ and $18.7 \%$ of girls $(n=37)$, said they had viewed online pornography before the age of 18 that had a strong effect on their attitudes or emotions (not shown in table). Asked about these strong reactions, boys were significantly more likely to report feeling sexual excitement ( $80 \%$ of boys, $27 \%$ of girls), while girls reported significantly more embarrassment $(73 \%$

\footnotetext{
${ }^{1}$ Penn State Harrisburg, Middletown, Pennsylvania.

${ }^{2}$ Crimes Against Children Research Center, University of New Hampshire, Durham, New Hampshire.
} 
Table 1. Characteristics of Exposure to Internet Pornography before Age 18

\begin{tabular}{|c|c|c|}
\hline & $\begin{array}{c}\text { Boys } \\
\mathrm{n}=192\end{array}$ & $\begin{array}{c}\text { Girls } \\
\mathrm{n}=371\end{array}$ \\
\hline \multicolumn{3}{|l|}{ Exposure to Internet pornography } \\
\hline Yes, before $18^{* *}$ & $93.2 \%$ & $62.1 \%$ \\
\hline Yes, after $18^{* * *}$ & 4.2 & 20.6 \\
\hline Never*** & 2.6 & 17.3 \\
\hline Exposure to Internet pornography before age 18 & $n=179$ & $n=226$ \\
\hline \multicolumn{3}{|l|}{ Age at first exposure } \\
\hline 8 & $0.6 \%$ & $0.0 \%$ \\
\hline 9 & 0.6 & 0.0 \\
\hline 10 & 0.6 & 0.5 \\
\hline 11 & 1.7 & 1.0 \\
\hline 12 & 10.9 & 7.7 \\
\hline 13 & 16.0 & 15.3 \\
\hline $14^{*}$ & 21.1 & 12.4 \\
\hline 15 & 22.9 & 22.5 \\
\hline $16^{* *}$ & 20.0 & 33.0 \\
\hline 17 & 5.7 & 7.7 \\
\hline Mean at first exposure ${ }^{* *}$ & 14.3 & 14.8 \\
\hline \multicolumn{3}{|l|}{ Number of times spent viewing for more than 30 minutes } \\
\hline Never*** & $30.6 \%$ & $76.8 \%$ \\
\hline Once & 6.9 & 9.1 \\
\hline Up to 10 times $^{* * *}$ & 27.8 & 11.4 \\
\hline More than 10 times*** & 34.8 & 2.7 \\
\hline Mean number of times spent viewing for more than 30 minutes $^{\mathrm{a} * * *}$ & 9.8 & 1.0 \\
\hline \multicolumn{3}{|l|}{ Reasons for viewing Internet pornography } \\
\hline Wanted the sexual excitement ${ }^{* * *}$ & $69.3 \%$ & $16.8 \%$ \\
\hline Curious about different things people do sexually*** & 53.1 & 26.1 \\
\hline Wanted information about sex ${ }^{* * *}$ & 39.7 & 19.5 \\
\hline With friends who wanted to do it ${ }^{* *}$ & 34.1 & 20.8 \\
\hline Never looked for pornography on purpose $\mathrm{e}^{\mathrm{b} * * *}$ & 6.8 & 42.3 \\
\hline \multicolumn{3}{|l|}{ Types of images seen at least once } \\
\hline Naked people but no sexual activity ${ }^{* * *}$ & $98.3 \%$ & $88.9 \%$ \\
\hline Mixed-sex intercourse ${ }^{* * *}$ & 93.8 & 73.5 \\
\hline Naked people showing genitals** & 91.1 & 81.0 \\
\hline Sexual activity among more than 2 people ${ }^{* * *}$ & 83.2 & 57.1 \\
\hline Same-sex intercourse ${ }^{* *}$ & 69.3 & 55.3 \\
\hline Sexual activity involving bondage $e^{* * *}$ & 38.6 & 22.6 \\
\hline Sexual activity between people and animals ${ }^{* * *}$ & 31.8 & 17.7 \\
\hline Sexual activity involving urine or feces & 21.8 & 16.4 \\
\hline Rape or sexual violence* & 17.9 & 10.2 \\
\hline Sexual pictures of children & 15.1 & 8.9 \\
\hline \multicolumn{3}{|l|}{ Mean number of times seen images ${ }^{c}$} \\
\hline Naked people but no sexual activity ${ }^{* * *}$ & 18.0 & 6.4 \\
\hline Naked people showing genitals $* * *$ & 16.5 & 5.3 \\
\hline Mixed-sex intercourse & 16.7 & 4.5 \\
\hline Sexual activity among more than 2 people ${ }^{* * *}$ & 12.5 & 3.2 \\
\hline Same-sex intercourse ${ }^{* * *}$ & 11.1 & 3.3 \\
\hline Sexual activity involving bondage $e^{* * *}$ & 3.2 & 0.9 \\
\hline Sexual activity between people and animals** & 1.6 & 0.6 \\
\hline Sexual activity involving urine or feces ${ }^{* *}$ & 1.5 & 0.5 \\
\hline Rape or sexual violence ${ }^{* *}$ & 1.1 & 0.3 \\
\hline Sexual pictures of children* & 0.9 & 0.3 \\
\hline TOTAL ${ }^{* * *}$ & 82.8 & 24.1 \\
\hline
\end{tabular}

aResponse choices were none, 1, 2-5 times, 6-10 times, 11-20 times, and more than 20 times. Each category was then recoded to its midpoint for number of times participant viewed pornography for 30 minutes or more (i.e., $0,1,3.5,8,15.5$, and 25.5).

${ }^{\mathrm{b}}$ To be coded as never looking for pornography on purpose, participants must have endorsed this item and indicated no other reason for looking at Internet pornography.

'Response choices were never, 1-5 times, 6-10 times, 11-20 times, 21-30 times, and more than 30 times. Each category was then recoded to its midpoint for number of images seen (i.e., $0,3,8,15.5,25.5$, and 35.5).

${ }^{*} p<0.05 ;{ }^{* *} p<0.01 ; * * * 00.001$. 
of girls, $25 \%$ of boys) and disgust (51\% of girls, $20 \%$ of boys). Over two-thirds of both boys and girls with strong effect experiences described feeling shock or surprise $(65 \%$ of boys, $78 \%$ of girls). Half of boys and about one-third of girls (32\%) felt guilt or shame. About equal numbers of boys and girls said that as a result of the encounter they were less eager to seek sexual activity ( $20 \%$ of boys, $22 \%$ of girls with strong effect experiences), had unwanted thoughts about the experience ( $25 \%$ of girls, $24 \%$ of boys), or felt unattractive or inadequate ( $15 \%$ of boys, $19 \%$ of girls).

\section{Discussion}

The young people in our sample had a considerable amount of exposure to Internet pornography during their teenage years. Nonetheless, we found considerable diversity in the extent of and reactions to exposure to online pornography. While many youth sought pornography, some were exposed involuntarily. Some wanted sexual stimulation, while others wanted information. Some accessed pornography frequently, others rarely. Most say online pornography did not have a strong effect on them, but some were strongly affected. Among those, some had mostly positive feelings, while others experienced guilt, embarrassment, and disgust.

The degree of exposure to paraphilic and deviant sexual activity before age 18 is of particular concern. In the case of child pornography, the viewing itself was probably a criminal act. ${ }^{3}$ Some boys had repeated exposure to pictures of sexual violence, raising concerns about established connections between pornography and sexual aggression among young men with aggressive tendencies. ${ }^{4}$

On the question of the effects of pornography on adolescents, few youth reported strong effects. Boys reported more sexual excitement and girls more embarrassment and disgust. However, responses were diverse. Some girls felt sexual excitement, and some boys were embarrassed or disgusted. Girls and boys both reported shock, surprise, guilt, shame, and unwanted thoughts about the experience. There was diversity both between and within genders, suggesting that relying on gender stereotypes about reactions to online pornography can obscure the full picture of how youth respond.
While this study provides noteworthy findings, generalizations cannot be made from this convenience sample, which includes retrospective reports from students at one public university with a largely homogenous student body.

For a topic of considerable public policy interest, the impact of Internet pornography exposure on young people has been subjected to little social scientific research. However, it is important for young people, as well as for public-policy decision makers, that we have basic facts about this issue. This study illustrates one model of how such facts can be obtained. We hope that success of these efforts will encourage others to seek empirical evidence to guide policy on the controversial issues that this topic engenders.

\section{Disclosure Statement}

The authors have no conflict of interest.

\section{References}

1. Finkelhor D, Mitchell KJ, Wolak J. (2000) Online victimization: a report on the nation's youth. Washington, DC: National Center for Missing \& Exploited Children.

2. Wolak J, Mitchell KJ, Finkelhor D. Unwanted and wanted exposure to online pornography in a national sample of youth Internet users. Pediatrics 2007; 119:247-57.

3. Klain EJ, Davies HJ, Hicks MA. (2001) Child pornography: the criminal-justice-system response. Washington DC: American Bar Association Center on Children and the Law.

4. Allen M, D'Alessio D, Brezgel K. A meta-analysis summarizing the effects of pornography II: aggression after exposure. Human Communication Research 1995; 22:258-83.

Address reprint requests to:

Dr. Chiara Sabina

Penn State Harrisburg

School of Behavioral Sciences and Education

777 West Harrisburg Pike

Olmsted Building W-311

Middletown, PA 17075

E-mail: sabina@psu.edu 


\section{This article has been cited by:}

1. Mary B. Short, Thomas E. Kasper, Chad T. Wetterneck. 2015. The Relationship Between Religiosity and Internet Pornography Use. Journal of Religion and Health 54, 571-583. [CrossRef]

2. Emma Sorbring, Jonas Hallberg, Margareta Bohlin, Therése Skoog. 2015. Parental attitudes and young people's online sexual activities. Sex Education 15, 129-143. [CrossRef]

3. R. Puglia, F. Glowacz. 2015. Consommation de pornographie à l'adolescence : quelles représentations de la sexualité et de la pornographie, pour quelle sexualité ?. Neuropsychiatrie de l'Enfance et de l'Adolescence . [CrossRef]

4. Chyng Sun, Ana Bridges, Jennifer Johnason, Matt Ezzell. 2014. Pornography and the Male Sexual Script: An Analysis of Consumption and Sexual Relations. Archives of Sexual Bebavior . [CrossRef]

5. Christina Mancini, Amy Reckdenwald, Eric Beauregard, Jill S. Levenson. 2014. Sex industry exposure over the life course on the onset and frequency of sex offending. Journal of Criminal Justice 42, 507-516. [CrossRef]

6. Alexandra Bailin, Ruth Milanaik, Andrew Adesman. 2014. Health implications of new age technologies for adolescents. Current Opinion in Pediatrics 26, 605-619. [CrossRef]

7. Anna Ševčíková, Kristian Daneback. 2014. Online pornography use in adolescence: Age and gender differences. European Journal of Developmental Psychology 1-13. [CrossRef]

8. Mariek Vanden Abeele, Scott W. Campbell, Steven Eggermont, Keith Roe. 2014. Sexting, Mobile Porn Use, and Peer Group Dynamics: Boys' and Girls' Self-Perceived Popularity, Need for Popularity, and Perceived Peer Pressure. Media Psychology 17, 6-33. [CrossRef]

9. Louis Leung. 2014. Predicting Internet risks: a longitudinal panel study of gratifications-sought, Internet addiction symptoms, and social media use among children and adolescents. Health Psychology and Behavioral Medicine 2, 424-439. [CrossRef]

10. Georgios Floros, Anna Paradisioti, Michalis Hadjimarcou, Demetrios G. Mappouras, Olga Karkanioti, Konstantinos Siomos. 2013. Adolescent Online Gambling in Cyprus: Associated School Performance and Psychopathology. Journal of Gambling Studies . [CrossRef]

11. Therése Skoog, Emma Sorbring, Jonas Hallberg, Margareta Bohlin. 2013. Boys' Pubertal Timing Measured on the Pubertal Development Scale is Linked to Online Sexual Activities. International Journal of Sexual Health 25, 281-290. [CrossRef]

12. Matija Sinković, Aleksandar Štulhofer, Jasmina Božić. 2013. Revisiting the Association between Pornography Use and Risky Sexual Behaviors: The Role of Early Exposure to Pornography and Sexual Sensation Seeking. Journal of Sex Research 50, 633-641. [CrossRef]

13. Jennifer Riemersma, Michael Sytsma. 2013. A New Generation of Sexual Addiction. Sexual Addiction \& Compulsivity 20, 306-322. [CrossRef]

14. Gert Martin Hald, Teguh Wijaya Mulya. 2013. Pornography consumption and non-marital sexual behaviour in a sample of young Indonesian university students. Culture, Healtb \& Sexuality 15, 981-996. [CrossRef]

15. Magdalena Mattebo, Tanja Tydén, Elisabet Häggström-Nordin, Kent W. Nilsson, Margareta Larsson. 2013. Pornography Consumption, Sexual Experiences, Lifestyles, and Self-rated Health Among Male Adolescents in Sweden. Journal of Developmental \& Bebavioral Pediatrics 34, 460-468. [CrossRef]

16. Paul J. Wright, Analisa Arroyo. 2013. Internet Pornography and U.S. Women's Sexual Behavior: Results From a National Sample. Mass Communication and Society 16, 617-638. [CrossRef]

17. Carmit Katz. 2013. Internet-related child sexual abuse: What children tell us in their testimonies. Children and Youth Services Review 35, 1536-1542. [CrossRef]

18. Paul J. Wright. 2013. Internet Pornography Exposure and Women's Attitude Towards Extramarital Sex: An Exploratory Study. Communication Studies 64, 315-336. [CrossRef]

19. Kevin C. Runions. 2013. Toward a Conceptual Model of Motive and Self-Control in Cyber-Aggression: Rage, Revenge, Reward, and Recreation. Journal of Youth and Adolescence 42, 751-771. [CrossRef]

20. Lucia F. O’Sullivan, Scott T. RonisSexual Development in Girls 193-219. [CrossRef]

21. Siu-ming To, Steven Sek-yum Ngai, Siu-mee Iu Kan. 2012. Direct and mediating effects of accessing sexually explicit online materials on Hong Kong adolescents' attitude, knowledge, and behavior relating to sex. Children and Youth Services Review 34, 2156-2163. [CrossRef]

22. Victor C. Strasburger, Amy B. Jordan, Ed Donnerstein. 2012. Children, Adolescents, and the Media:. Pediatric Clinics of North America 59, 533-587. [CrossRef] 
23. M. Deborah Corley, Joshua N. Hook. 2012. Women, Female Sex and Love Addicts, and Use of the Internet. Sexual Addiction \& Compulsivity 19, 53-76. [CrossRef]

24. Eric W. Owens, Richard J. Behun, Jill C. Manning, Rory C. Reid. 2012. The Impact of Internet Pornography on Adolescents: A Review of the Research. Sexual Addiction \& Compulsivity 19, 99-122. [CrossRef]

25. Carl Göran Svedin, Ingrid Åkerman, Gisela Priebe. 2011. Frequent users of pornography. A population based epidemiological study of Swedish male adolescents. Journal of Adolescence 34, 779-788. [CrossRef]

26. Virginia Fisoun, Georgios Floros, Dimitrios Geroukalis, Nikoleta Ioannidi, Nikiforos Farkonas, Elena Sergentani, Nikiforos Angelopoulos, Konstantinos Siomos. 2011. Internet addiction in the island of Hippocrates: the associations between internet abuse and adolescent off-line behaviours. Child and Adolescent Mental Health no-no. [CrossRef]

27. Marie-Thérèse Luder, Isabelle Pittet, André Berchtold, Christina Akré, Pierre-André Michaud, Joan-Carles Surís. 2011. Associations Between Online Pornography and Sexual Behavior Among Adolescents: Myth or Reality?. Archives of Sexual Behavior . [CrossRef]

28. Barbara Krahé. 2011. Pornografiekonsum, sexuelle Skripts und sexuelle Aggression im Jugendalter. Zeitschrift für Entwicklungspsychologie und Pädagogische Psychologie 43, 133-141. [CrossRef]

29. Sjoerd Beugelsdijk, Arjen Slangen. 2010. The Impact of National Cultural Distance on the Number of Foreign Web Site Visits by U.S. Households. Cyberpsychology, Behavior, and Social Networking 13:2, 201-205. [Abstract] [Full Text HTML] [Full Text PDF] [Full Text PDF with Links]

30. Michael Flood. 2009. The harms of pornography exposure among children and young people. Child Abuse Review 18:10.1002/ car.v18:6, 384-400. [CrossRef]

31. Kareena McAloney, Joanne E. WilsonYoung People, Sexual Content and Solicitation Online 338-356. [CrossRef] 